\title{
Apuntes
}

\section{Catedrales andaluzas en internet}

Susana Limón Rodriguez

Centro de Documentación del IAPH

\section{Almería}

Catedral de Nuestra Señora de la Encarnación

http://usuarios.lycos.es/juancato/seos/almeria.htm?

En esta sede se encuentra una breve descripción histórico-artística del templo acompañada de imágenes.

\section{Cádiz}

Catedral Nueva de Cádiz

\section{Turismo, Ocio y Cultura en la provincia de Cádiz}

http://www.cadiznet.com

En la sección Monumentos, encontramos un enlace a los templos, donde puede realizarse una consulta a toda la provincia o a los diferentes templos según sus denominaciones. En este caso encontramos una referencia a la catedral Nueva de Cádiz con acceso a detalles del interior, exterior, presbiterio, coro y cripta.

Para la Catedral de Santa Cruz o Catedral Vieja de Cádiz (conocida también como Iglesia Parroquial del Sagrario) y la Catedral del Salvador (Jerez), consúltese Monumentalia

\section{Córdoba}

Catedral de la Asunción de Nuestra Señora

(Mezquita-catedral de Córdoba)

\section{Ciudades Patrimonio}

http://www.ciudadespatrimonio.org/ciudades/cordoba/ catedral.htm

Encontramos entre todos los elementos que se analizan de la ciudad una breve descripción e imágenes de la Catedral.

\section{puebloApueblo.com}

http:/ / www.puebloapueblo.com/report.asp?rep=11

Reseña histórica de la evolución de la Mezquita-Catedral a lo largo del tiempo.

\section{Granada}

Catedral de la Anunciación (Granada)

Guía de Granada: catedral y capilla real

http://www.moebius.es/ggranada/monu/catedral.htm

Descripción de la catedral, capilla real y museo con fotografías y planos de los mismos

Para la Catedral de la Encarnación (Guadix), véase Monumentalia

\section{Huelva}

Iglesia y Antiguo Convento de la Merced

\section{Gabinete Pedagógico}

http:/ / www.juntadeandalucia.es/averroes/gpba/huelva/visitas/ I.\%20de\%20la\%20Merced,\%20Huelva/I.\%20de\%20la\%20Mer ced,\%20Huelva.htm
Encontramos un estudio detallado de la iglesia-catedral con una ficha básica: descripción, planos y fotografías, así como bibliografía de interés.

\section{Jaén}

Catedral de la Asunción de la Virgen (Jaén)

\section{Visita guiada a la Catedral de Jaén}

http://www.iglesiajaen.com/principal.htm

Visita guiada por los diferentes elementos así como un amplio álbum de fotos de la visita.

\section{Guía Monumental de Jaén}

http://www.jaenonline.com/yayyan/arte/ monum-22-arte-02.htm

Descripción pormenorizada de sus elementos a lo largo de la historia.

\section{Málaga}

Catedral de la Encarnación

Consúltense Monumentalia e Inventario de las campanas

\section{Sevilla}

Iglesia Catedral de Santa María

\section{La Montaña Hueca}

http://www.arquired.es/users/giralda/catsev.htm Datos generales, historia del templo, descripción formal y funcional, así como imágenes y publicaciones entre otros contenidos de interés.

\section{Turismo y Cultura de Sevilla}

http://www.hispalis.net/

Ofrece una descripción pormenorizada de todos los elementos y capillas que componen la iglesia catedral. Muestra además una versión en inglés.

\section{Generales}

\section{Monumentalia:}

http://www.monumentalia.net/

En esta sede encontramos un listado de todas las catedrales de España, entre ellas las andaluzas.

Para cada catedral se accede a una ficha que cuenta con algunos de los siguientes apartados de interés: descripción e imagen del templo, vista panorámica del templo, galería fotográfica, enlaces de interés y comentarios de los usuarios.

\section{Inventario de las campanas}

http:// www.cult.gva.es/scripts/gcv/general.idc?

En esta página de la Conselleria de Cultura i Educació de la Generalitat Valenciana encontramos un inventario de las campanas de las Catedrales españolas, entre ellas las andaluzas. 